\title{
Pendampingan Budidaya Dan Usaha Tanai Talas Jepang (Colocasia Esculenta Var. Antiquorum) Di Sinjai Sulawesi Selatan
}

\author{
Masyhur Syafiuddin ${ }^{1}$, Nurbaya Busthanul ${ }^{2}$, Muhammad Jayadi ${ }^{3}$, Andi Masniawati ${ }^{4}$, Tamzil Ibrahim ${ }^{5}$
}

1,3 Program Studi Agroteknologi Fakultas Pertanian Universitas Hasanuddin, Makassar

2,5 Program Studi Agribisnis Fakultas Pertanian Universitas Hasanuddin, Makassar

${ }^{4}$ Program Studi Biologi Fakultas MIPA Universitas Hasanuddin, Makassar

Email: masyhurs.akademik@gmail.com

\begin{abstract}
Abstrak
Penerapan teknologi budidaya dan usaha talas jepang (Colocasia esculenta var. antiquorum) untuk produksi massal dan berkualitas telah dikembangkan di beberapa wilayah. Namun demikian, teknologi yang memang jadi tuntutan para buyer utama khususnya dari Jepang, belum diterapkan secara baik di kalangan petani dan calon petani talas potensial. Karena itu diperlukan sosialisasi dan desiminasi teknologi secara intensif melalui pendampingan. Tujuan pendampingan talas yang sering juga disebut satoimo ini adalah untuk meningkatkan kemampuan petani dan calon petani mitra/binaan Perusahaan khususnya di Kabupaten Sinjai melalui pelibatan masyarakat Perguruan Tinggi. Sedang target khususnya adalah meningkatnya ketrampilan patani dalam teknik budidaya dan usaha tani yang ditandai dengan tingkat ketepatan menjawab dan mempraktikkannya, serta meningkatnya produktivitas dan kualitas hasil panennya. Metode yang digunakan adalah metode pelatihan dengan sarana DEMPLOT (petak percontohan) yang ditunjang dengan pembelajaran teori di kelas. Secara garis besar, materi pelatihan terdiri atas: teknik pembibitan, budidaya di lapangan (kebun pembesaran), dan aspek usaha taninya. Keseluruhan proses tersebut memakan waktu tujuh bulan. Hasil pelaksanaan kegiatan menunjukkan 85 persen dari peserta dapat menjawab dengan benar secara tertulis, dan 70 dapat melakukan dengan benar secara praktik (mempraktikkan). Hasil analisis usaha tani talas satoimo untuk lokasi pelatihan menguntungkan petani dengan BCR 1,82. Pada pasca pelatihan, terdapat delapan puluh presen peserta mengaku akan melanjutkan rencana usaha budidaya satoimo, meningkat dari yang sebelumnya kurang dari separuhnya. Secara keseluruhan pelatihan cukup efektif.
\end{abstract}

Kata kunci: talas jepang, satoimo, teknologi budidaya, pendampingan.

\section{PENDAHULUAN}

Latar Belakang. Talas jepang (Colocasia esculenta var. antiquorum) yang juga sering disebut satoimo (talas safera, Jawa Barat) memiliki kandungan nutrisi yang cukup tinggi, dengan kandungan protein tinggi $8,85 \%$ sedangkan kandungan lemak $0,56 \%$ lebih rendah dari talas pada umumnya $1,64 \%$, pati $(63,51) \%)$, amilosa $11,10 \%$, amilopektin 52,91\%, kalori 92,30kal, karbohidrat $16,33 \mathrm{~g}$, kalsium $9 \mathrm{mg}$, fosfor $5 \mathrm{~g}$ dan kadar serat 16,18\% (Heni Purwaningsih and Umi Pudji Astuti, 2018). Darkwa mendapatkan, tepung talas mengandung abu $4.01 \%$, protein $3.43 \%$, karbohidrat $0.74 \%$, bahan kering $85.32 \%$, and lemak $0.18 \%$ (Darkwa, 2013). Secara nutrisional, talas memiliki 
kandungan vitamin dan nutrisi yang lebih luas (beragam) dibandingkan dengan tanaman umbiumbian lainnya. Begitu pentingnya perannya, di negara-negara Afrika talas digelari 'raja' sementara yam digelari 'ratu' (Raliya et al., 2013). Talas merupakan salah satu tanaman umbi dan umbi yang ditanam untuk berbagai keperluan; dibudidayakan sebagian besar oleh petani skala kecil dan digunakan sebagai tanaman pangan pokok di banyak negara berkembang di Asia dan Afrika (Banjaw, 2017). Sekitar 400 juta penduduk dunia terutama di negaranegara kepulauan Pasifik (PICTs) menjadikan talas sebagai makan pokoknya (Ubalua, Ewa, \& Okeagu, 2016). Talas memang merupakan tanaman pangan yang tersebar luas dan penting di daerah tropis lembab dan subtropis; di Cina pun terutama di Han talas banyak dibudidayakan (Jianchu, Yongping, Yingdong, Ayad, \& Eyzaguirre, 2001)

Jenis sumber pangan tradisional masyarakat Jepang ini sangat dibutuhkan dan diimpor oleh Jepang terutama dari Tiongkok dan sangat potensil dipasok dari Indonesia. Jepang meminta ke Indonesia rata-rata 2.500 ton frozen per bulan atau setara dengan tujuh sampai sepuluh ribu ton umbi segar. Impor Jepang rata-rata 45.000 ton frozen per tahun, tidak jauh berbeda dengan keadaan impor tercatat pada tahun satu setengah decade sebelumnya. Pada tahun 2003 total impor satoimo dunia ke Jepang adalah sekitar 30 ribu ton segar dan 50 ribu ton frozen (David Midmore, Daniel White, Vong Nguyen, David Hicks, Eric Coleman, Suzie Newman, Phillip Wilk, 2006). Berdasarkan penilaian $\mathrm{RC}$ ratio ( $\mathrm{RCR}>1$ ), dapat disimpulkan talas satoimo memang layak diusahakan (Muhammad Nagano, Sunaryo, 2016); bahkan hingga 2,07 (Amelia \& Yumiati, 2016). Terkait hal tersebut Pemerintah Sulawesi Selatan dengan antusias menetapkannya sebagai salah satu komoditi andalan penggerak perekonomian Daerah sejak 2018. Perluasan tanam pun melalui bantuan permodalan petani mulai diimplementasikan pada tahun 2019; dimulai di sepuluh kabupaten.

Kabupaten Sinjai Sulawesi Selatan, tanaman talas jepang secara spot-spot di beberapa tempat sejak lima tahun terakhir telah dikenal dan dicoba ditanam oleh masyarakat dalam skala kecil. 'Pengujian' itu merupakan bagian dari respon masyarakat atas program pertalasan di Kabupaten Bantaeng yang sudah lebih awal (satu dekade) mengembangkan dan berhasil mengekspor talas serupa. Namun belum memberi hasil yang memuaskan. Padahal tanah dan iklim di Kabupaten Sinjai memiliki indikasi kuat "sesuai" untuk talas. Karena itu sangat boleh jadi teknik budidaya dan atau pemilihan lokasi yang tidak tepat. Bantaeng yang telah membuka pitu ekspor, telah beberapa kali melakukan ekspor produk talas frozen ke negeri Sakura yang merupakan konsumen terbesar dunia memang telah menarik perhatian masyarakat (petani) di beberapa kabupaten untuk mengembangkan talas terkhusus wilayah kabupaten yang berdekatan, termasuk Kabupaten Sinjai. Disadari atau tidak esksisten pintu ekspor itu menjadi "wajib" dipertahankan karena memasukkan makanan yang marketable ke pasar negeri sekelas Jepang tidaklah mudah. Karena itu dibutuhkan konsistensi untuk membudidayakan talas secara ramah lingkungan (eco-farming). Oleh sebab itu maka tuntutan akan teknik budidaya talas yang berproduksi tinggi, menguntungkan secara ekonomi dan ramah lingkuperngan mutlak diperlukan oleh masyarakat petani dan calon petani talas. Karena itu implementasi ramah lingkungan juga menjadi tanggung jawab semua pihak untuk melakukannya. Terkait dengan hal-hal di atas maka diperlukan implementasi teknologi budidaya ramah lingkungan terkhusus pada proses produksi umbi talas jepang untuk keperluan bahan baku talas kualitas ekspor terutama di kalangan petani talas jepang di kabupaten Sinjai.

Mencermati masalah tersebut, Unhas sebagai lebaga pendidikan tinggi yang mumpuni yang memiliki sumber daya IPTEKS diharapakan berkontribusi untuk membantu menyelesaikan persoalan-persoalan ramah lingkungan talas di lapangan. Terlebih lagi setelah Rektor Unhas menetapkan pemusatan Pengabdian Masyarakat yang dirangkaikan dengan acara Dies Natalis 2018 di Sinjai (dan Enrekang). Program atau skim pengabdian yang dikemas dalam skim PPMDU-IbW 
menjadi kondisi yang sangat memberi peluang emas bagi Unhas membawa teknologi ramahlingkungannya untuk diterapkan di kalangan petani talas di Sinjai. Hasil-hasil penelitian talas jepang khususnya yang dilakukan di Kabupaten Gowa dan kabupaten lainnya di Sulawesi Selatan, serta dari hasil-hasil temuan lainnya dapat mejadi rujukan yang efektif meningkatkan kapasitas petani dalam proses produksi talas jepang yang efektif dan efisien. Berbagai penelitian telah dilaksanakan terutaama menyangkut pemupukan, pengendalian hama dan penyakit tanaman dan teknologi budidaya lainnya.

Permasalahan sesungguhnya adalah tingkat pengetahuan dan ketrampilan patani yang masih relatif rendah; terlebih karena komoditi satoimo merupakan komoditi relatif 'baru' dalam sistem pertanian tradisional petani. Petani membutuhkan bimbingan atau pembinaan yang intensif dan kontinyu oleh pihak atau tenaga yang berilmu dan teknologi serta berpengalaman di bidang budidaya talas. Oleh sebab itu permasalahan pokok yang harus dipecahkan bersama adalah: (i) bagaimana meningkatkan kemampuan petani melakukan teknik budidaya ramah lingkungan untuk menghasilkan produksi dengan produktivitas dan kualitas yang secara ekonomi menguntungkan yang dengan demikian usahataninya dapat berkelanjutan (sustainable); dan (ii) bagaimana meningkatkan pemahaman dan ketrampilan petani talas jepang melakukan analisis usahatani sehingga dapat mengerti bahwa keputusan memeilih teknik budidaya tertentu adalah benar, termasuk untuk memutuskan memilih teknik budidaya talas jepang yang ramah-lingkungan.

Berdasarkan kondisi-kondisi tersebut di atas maka dilakukan kerjaama secara institusional antara Univesitas Hasanuddin dan Pemda Sinjai yang lebih terarah, terencana sehingga lebih efektif dan saling menguntungkan sesuai permasalahan utama yang dihadapi petani terutama yang terkait tingkat produksi dan kualitas hasil panen yang masih rendah. Dari banyak pertimbgan, maka dirancang pendekatan pendampingan dengan sarana demplot untuk menyelesaikan masalah yang dihadapi petani calon petani talas di Sinjai.

Tujuan dan Rencana Penanganan Masalah. Tujuan kegiatan adalah melakukan pendampingan bagi petani talas pemula dan calon petani talas untuk mengembangkan ketrampilan bercocok tanam dan memberi wawasan mengenai usaha tani talas serta kemampuan menyusun analisis rencana investasi talas pada level sederhana.

Tinjauan Pustaka. Hasil-hasil penelitian, satoimo tumbuh dan menghasilkan optimal pada kondisi lahan terbuka dengan kata lain penyinaran matahari penuh (sepanjang hari). Namun mampu tumbuh berbayang (ternaungi) hingga $70 \%$. Penelitian lain yang telah menguji 20 varietas talas; hasilnya menunjukkan bahwa pada naungan 25\% terdapat 16 klon talas toleran dan 4 klon peka. Pada naungan 50\% terdapat 9 klon toleran dan 11 klon peka, sedangkan pada naungan $75 \%$ terdapat 7 klon toleran dan 13 klon peka. Peningkatan luas daun dan kadar klorofil a dan $\mathrm{b}$ klon toleran lebih tinggi dibandingkan klon peka (Djukri dan Bambang Sapta Purwoko, 2003). Khusus untuk talas satoimo atau yang di Bali disebut talas salak penurunan hasil terjadi sejalan dengan persen naungan. Dengan 25\% naungan, produksi menjadi $70,9 \%$, naungan $50 \%$ produksi menjadi $64,0 \%$, dan naungan $75 \%$ produksi menjadi $60,3 \%$. Juga telah dilakukan variasi naungan dengan tegakan pohon. Jenis tegakan jabon memberikan hasil biomassa tanaman talas $(366,57$ $\mathrm{g} /$ tanaman) paling baik dibanding pada tegakan sengon (266,15 g/tanaman), manglid (175,64 g/tanaman) dan monokultur (182,98 g/tanaman). Intensitas cahaya di bawah tegakan jabon dalam sistem agroforestri adalah $41,17 \%$. Jenis tegakan berpengaruh nyata terhadap pertumbuhan dan produksi tanaman bawah talas dalam sistem agrofrestri (Hani, 2014). Dari segi tanah, talas menyukai tanah gembur. Hal yang tidak kalah pentingnya adalah pengairan karen tanaman talas sangat konsumtif air (Jensen Uyeda, Ted Radovich, Jari Sugano \& Water, 2011)

Sub Tema Ekonomi, Sosial, dan Budaya

1002 
Potensi produksi di tanah berpasir lebih tinggi $(3,4$ $\mathrm{kg} / \mathrm{m} 2)$ daripada di pekarangan $(2,04 \mathrm{~kg} / \mathrm{m} 2)$ (Heni Purwaningsih and Umi Pudji Astuti, 2018). Dari perspektif penyinaran dan tanah dapat disimpulkan bahwa, talas menyukai dan hendaknya ditanam di tempat terbuka meski masih bisa di tempat ternaungi, serta pada tanah yang gembur (tidak padat). Tidak ada persyaratan khusus yang signifikan atau ekstrim berbeda dengan kebutuhan tanaman pada umumnya. Secara umum kebutuhan dasar tanaman adalah tanah yang berdrainase baik, tekstur tanah yang agak halus sampai sedang, bebas dari pengaruh kegaraman tinggi, dan syarat lingkungan fisik lainnya (Mishra, 2007).

Dalam menyukseskan program pengembangan pertanian sering dilakukan pendampingan. Makna sesungguhnya pendampingan adalah terhadap petani. Di dalam penyuluhan tidak ada unsur paksaan, selalu menjaga batin peserta didik (petani). Dalam penyuluhan tidak saja membangun intelektualitas dan ketrampilan petani namun membangun manusia sosial budaya. Selanjutnya, Pendampingan penyuluh adalah serangkaian kegiatan fasilitasi yang dilakukan oleh penyuluh dalam proses pembelajaran petani melalui penerapan berbagai metode penyuluhan, diantaranya, kursus tani desa, rembug tani desa, Farmers Field Day, dll. (BKPP DI Yogyakarta, 2015). Filosofinya, suatu pendampingan dikatakan efektif mendorong adopsi teknologi kepada petani jika apa yang dilakukan pendamping sama dengan apa yang diinginkan oleh petani yang didampinginya. Jika pendamping melakukan kegiatan yang tidak diinginkan petani, kegiatan itu dipandang pemborosan. Sementara itu, yang harus menjadi prioritas pendampingan adalah pada kondisi petani menginginkan adanya perlakuan tertentu tetapi tidak belum dilakukan pendamping (Pribadi, 2016). Hasil penelitian menemukan bahwa terdapat pengaruh kuat peran pendamping terhadap keberhasilan Simantri melalui produksi usaha Simantri di Kabupaten Badung (Aryana, Budhi, \& Yuliarmi, 2016). Peneliti lainnya menemukan, tingkat partisipasi petani yang mendapat
Gambar 1. Sosialisasi Program di rumah Ketua Kelaompok Tani Target.Nomor 1 dari kanan Ketua Tim

pendampinganlebih besar daripada tingkat partisipasi petani yang tidak mendapatkan pendampingan dalam melaksanakan program swasembada dan swasembada berkelanjutan di Kota Padangsidimpuan (Dedi Wahyudi, 2015). Pendampingan dengan sarana praktek berupa demplot (demonstration plot) diyakini dapat memberi hasil yang lebih efektif dan efisien.

\section{METODE PELAKSANAAN}

Pendampingan petani talas dilakukan di Kecamatan Sinjai Timur Kabupaten Sinjai, Juni sampai November 2018, dirangkaikan dengan (menjadi bagian dari) program prngabdian kepada masyarakat yang dipusatkan pada dua kabupaten (termasuk Kabupaten Enrekang) tempat pemusatan pengabdian kepada masyarakat dalam rangka Dies Natalis Unhas 2018.

Metode yang diterapkan adalah pendampingan teknik budidaya dan manajemen usaha tani talas jepang melalui media DEMPLOT dan kelas/ruang belajar. Demplot tersebut mempragakan unsur-unsur (item) rangkaian teknik budidaya terutama cara pemupukan yang berbeda. Inovasi yang diajarkan di lapangan (pada demplot) selalu didahului dengan penjelasan teori di kelas. Materi yang diajarkan secara garis besar meliputi tiga hal pokok: (i) Teknologi Pembibitan; (ii) inovasi/teknologi budidaya ramah-lingkungan di kebun pembesaran; dan (iii) Dasar-dasar pengetahuan analisis ekonomi usahatani spesifik talas jepang. Adapun materi pembelajaran/percontohan meliputi 10 topik: (1) 
Wawasan mengenai perkembangan bisnis talas jepang, dan pemasaran talas jepang; (2)

Gambar 2. Tim dan peserta berfoto sesaat acara pembukaan dimulai. Nampak peserta antusias memegang alat peraga berupa bibit talas pemilihan/penentuan lokasi yang sesuai; (3) penyiapan tanah/lahan (pembersihan dan pengolahan tanah), (4) pemilihan benih/bibit, penyiapan benih, dan pendederan benih; (5) penanaman bibit (dari pendederan); (6) perawatan yang terdiri atas pengairan; dan (7) penyiangan; (8) pemupukan dan (9) perlindungan dari hama dan penyakit; dan (10) dan pasca-panen; serta (11) Analisis ekonomi dan pengembngan bisnis talas jepang. Gambar 1 mencerminkan suasana intensifnya pelatihan dengan alat peraga sesuai materi pengajaran. Meskipun tanaman ini termasuk tanaman lahan kering, namun talas sangat konsumtif air bahkan menyerupai tanaman padi (Jensen Uyeda, Ted Radovich, Jari Sugano \& Water, 2011).

Kegiatan pelatihan teknik bercocok tanam (mulai persiapan tanah sampai panen dan pasca-panen) memerlukan waktu enam bulan penuh. Seluas 0,20 hektar dengan 6 ribu populasi akan dikelompokkan ke dalam berbagai treatment (perlakuan) yang berbeda-beda untuk menunjukkan pada peserta binaan pengaruh setiap prlakuan. Penanaman dilakukan pertengahan Juni dan panen pada awal November 2018 (empat setengah bulan). Sebanyak lima pakar dari berbagai keahlian dari Fakultas Pertanian dan Fakultas MIPAUnhas dan staf dari Pemda Sinjai secara bergiliran memberi materi pelatihan sesuai kepakarannya dan didampingi oleh dua mahasiswa untuk mendukung kelancaran dan keamanan pelatihan di kelas dan di lapangan.

Pelaksanaan praktik di lapangan dengan demplot sejalan dengan teori yang diberikan di kelas. Setiap materi yang diberikan di kelas diikuti dengan pelaksanaan di lapangan (lokasi DEMPLOT). Dua hal yang paling ditekankan dalam percontohan budidaya yakni efek atau pengaruh pemupukan, dan pembumbunan. Namun demikian seluruh rangkaian teknik budidaya tetap diaplikasikan sebagai prasyarat budidaya secara normal. Untuk kepentingan itu maka dibuat variasi perlakuan: Pemupukan dengan kompos tiga taraf: 0, 500, dan 1000 gram per tanaman (P0, P2, dan P3). Sedang pembumbunan dengan dua taraf: tanpa dibumbun, dan dibumbun dua kali yakni setiap kali dilakukan penyiangan dirangkaikan pemupukan susulan (B0 dan B1). Perlakuan dasar (non-pengujian) masingmasing tanaman diberi perlakuan sama dalam hal pupuk NPK 20 gram (kurang lebih 1 sendok makan) masing-masing pada umur 0,45 , dan 90 hari sesudah tanam; setara 60 gram per tanaman.

Untuk mengukur tingkat efektivitas pelatihan dilakukan pre dan post-test secara garis besar terkait materi (11 topik) yang diberikan selama pelatihan/pendampingan. Pada akhir acara ditanyakan pula tentang siapa yang berniat memulai (bagi calon peani talas) atau melanjutkan (bagi yang sudah memulai bertanam talas).

\section{HASIL DAN PEMBAHASAN}

Hasil pelaksanaan pelatihan secara umum mencapai target dan dipaparkan pada acara pertemuan (seminar hasil) Dies Natalis di Sinjai, meskipun belum seluruh rangkaian kegiatan pelatihan berakhir disebabkan seminar tersebut menyesuaikan dengan jadwal acara dies natalis UNHAS yang lebih awal daripada waktu berakhirnya kegiatan pelatihan. Keseluruhan materi pelatihan diterapkan sesuai rencana. Secara rinci dapat dijelaskan sebagai berikut.

Sub Tema Ekonomi, Sosial, dan Budaya 


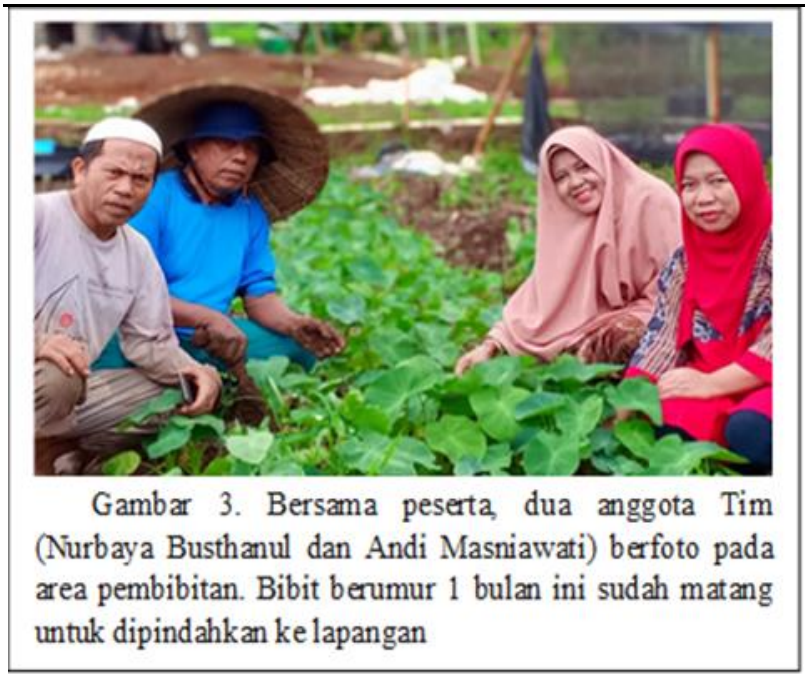

Materi yang diajarkan. Sebelas (11) materi pembelajaran (seperti tercantum pada METODE) dapat disajikan seluruhnya dalam lima kali pertemuan. Dengan demikian terdapat enam kali kunjungan selama pelatihan termasuk kunjungan awal untuk sosialisasi dan survei pemilihan/penentuan lokasi demplot.

Kemampuan teknik budidaya. Hasil test menunjukkan menunjukkan 85 persen dari peserta dapat menjawab dengan benar secara tertulis, dan 70 dapat melakukan dengan benar secara praktik (mempraktikkan); dibandingkan pada pre-test hanya mencapai 36 persen dan 15 persen scara berturuturut. Fakta hasil panen menunjukkan tingkat keberhasilan budidaya yang cukup baik yakni sekitar 80 persen dari populasi tanaman menghasilkan dengan rata-rata produksi $2 \mathrm{~kg} / \mathrm{tanaman}$ atau sekitar 40 ton per hektar, lebih tinggi daripada produksi talas di Luwuk Banggai. Produktivitas talas satoimo dengan luas panen 512 hektar dan produksi rata-rata $11.909,26$ ton/ha (Saidah \& Syafruddin, 2014). Di Sulawesi Selatan berdasarkan beberapa percobaan, dapat mencapai 40 ton/ha. Dengan nilai pasar yang berlaku, dapat dihasikan 100 juta rupiah atau lebih dengan $\mathrm{R} / \mathrm{C}$ ratio 2 atau lebih. Penelitian lain menemukan, Tingkat produktivitas klon Jepang (BGH 5925) ditanam pada jarak tanam 0,90 x 0,30 $\mathrm{m}$. Dalam dua tahun percobaan, hasil meningkat di hampir semua kelas umbi dengan kenaikan tarif $\mathrm{N}$. Perkiraan hasil maksimum umbi yang dapat dipasarkan adalah 22,23 $\mathrm{Mg} \mathrm{ha}^{-1}$ (Vidigal, Lopes, Puiatti, Sediyama, \& Ribeiro, 2016).

\section{Analisis Ekonomi Praktek}

Gambar 5. Bersama Ketua Aset Unhas mengenalkan talas frozen siap ekspor pada acara Pameran IPTEK UNHAS.

Gambar 4. Ketua Tim menjelaskan ragam talas satoimo kepada Bupati Enrekang (jas hitam dan topi) pada acara Seminar hasil PPM Unhas.

Budidaya. Analsis diarahkan kepada parameter ekonomi sederhana yakni benfit-cost ratio (BCR). Unit usaha diskenariokan dalam satu hektar, yang merupakan konversi dari kegiatan ril di lapangan selama pelatihan. Hasil analisis menujukkan, usaha budidaya talas satoimo di Kecamatan Sinjai Timur Kabupaten Sinjai cukup menguntungkan. Nilai BCR sebesar 1,82 yang berarti setiap korbanan atau pemanfatan biaya sebesar 1,0rupiah akan menghasilkan keuntungan (profit) sebesar 0,82 rupiah. Hasil analisis secara rinci diperlihatkan pada Tabel Lampiran 1.

Efektivitas Pelatihan. Di akhir pengajaran telah dilakukan posttest menurut materi yang telah diajarkan di kelas dan di lapangan. Peserta sebanyak 20 orang yang dapat menyelesaikan pelatihan hingga akhir dapat menjawab pertanyaan dengan benar sebanyak 85 persen untuk pertanyann di kelas, dan

Sub Tema Ekonomi, Sosial, dan Budaya 
70 persen untuk praktek di lapangan. Yang menarik adalah, jika pada awal pelatihan di buka, hanya terdapat kurang dari setengah jumlah peserta yang yakin akan meneruskan berusaha tanaman talas satoimo, namun setelah pelatihan hampir seluruh peserta yakin akan meneruskan berusaha satoimo. Hanya empat atau 20 persen yang tidak berniat meneruskan, namun karena alasan usaha budidaya talas satoimo berbiaya mahal dan berisiko tinggi. Hal ini menunjukkan bahwa pelatihan yang dilaksanakan memiliki efektivitas yang cukup tinggi (berhasil guna).

\section{KESIMPULAN DAN SARAN}

Hasil pelaksanaan kegiatan "Pendampingan Budidaya dan Usaha Tanai Talas Jepang (Colocasia esculenta var. antiquorum) di Sinjai Sulawesi Selatan" menunjukkan 85 persen dari peserta dapat menjawab dengan benar secara tertulis, dan 70 dapat melakukan dengan benar secara praktik (mempraktikkan). Hasil analisis usaha tani talas satoimo untuk lokasi pelatihan menguntungkan petani dengan BCR 1,82. Pada pasca pelatihan, terdapat delapan puluh presen peserta mengaku akan melanjutkan rencana usaha budidaya satoimo, meningkat dari yang sebelumnya kurang dari separuhnya. Secara keseluruhan pelatihan cukup efektif. Investasi usaha tani talas jepang bagi petani di Sinjai Timur dapat disarankan.

\section{UCAPAN TERIMAKASIH}

Ucapan terima kasih disampaikan kepada Ketua LPPM UNHAS dan Pemerintah Kabupaten Sinjai yang telah memberikan biaya untuk penyelenggaraan pengabdian ini. Juga kepada Pemerintah Kabupaten Enrekang atas kerjasama Pengabdian ini.

\section{REFERENSI}

Amelia, D. D., \& Yumiati, Y. (2016). Analisis Usahatani Talas Satoimo (Colocasia esculenta var. antiqourum) (Studi Kasus: di Desa Suka Sari Kecamatan Kabawetan Kabupaten
Kepahiang). Agritepa, 2(2), 188-198. Retrieved from file:///C:/Users/Dell/Downloads/302-Article Text-861-1-10-20160813.pdf

Aryana, A. A. N. B., Budhi, M. K. S., \& Yuliarmi, N. N. (2016). Pengaruh Karakteristik Petani Dan Peran Pendamping Terhadap Keberhasilan Simantri Di Kabupaten Badung. E-Jurnal Ekonomi Dan Bisnis Universitas Udayana, 4(5), 689-720.

Banjaw, D. T. (2017). Review of Taro (Colocasia esculenta) Genetics and Breeding. Journal of Horticulture, 04(01), 1-4. https://doi.org/10.4172/2376-0354.1000196

BKPP DI Yogyakarta. Efektivitas Pendampingan Petani (2015). Yogyakarta: BKP dan Penyuluhan (10) D.I. Yogyakarta. Retrieved from

https://www.google.com/search?q=efek+pend ampingan+petani\&oq=\&aqs $=$ chrome. 0.69 i591 $8.14778995 \mathrm{j} 0 \mathrm{j} 7 \&$ sourceid=chrome \&ie=UTF8

Darkwa, S. (2013). TARO "Colocasia esculenta": It's Utilization in Food Products in Ghana. Journal of Food Processing \& Technology, 04(05). $\quad$ https://doi.org/10.4172/21577110.1000225

David Midmore, Daniel White, Vong Nguyen, David Hicks, Eric Coleman, Suzie Newman, Phillip Wilk, D. R. and P. M. (2006). Development of taro, yam, yam bean and sweet potato exports to Japan and USA Prof David Midmore Central Queensland. Sydney NSW: Horticulture Australia Ltd. Retrieved from https://www.google.com/search?q=Developm ent+of+taro $\% 2 \mathrm{C}+$ yam $\% 2 \mathrm{C}+$ yam+bean+and $+\mathrm{s}$ weet+potato+exports+to+Japan+and+USA\&o $\mathrm{q}=$ Development + of + taro $\% 2 \mathrm{C}+\mathrm{yam} \% 2 \mathrm{C}+\mathrm{yam}$ +bean+and+sweet+potato+exports+to+Japan+ and+USA\&aqs=chrome..69i57.3109j0j7\&sour ceid $=$ chrome $\&$ ie $=U$ TF- 8

Dedi Wahyudi. (2015). Urgensi Pendampingan Terhadap Tingkat Partisipasi Petani dalam Pelaksanaan Program Swasembada dan Swasembada Berkelanjutan di Kota Padangsidimpuan. Agrica Ekstensia, 10(1), 57-61.

Sub Tema Ekonomi, Sosial, dan Budaya

1006 
Djukri dan Bambang Sapta Purwoko. (2003). PENGARUH NAUNGAN PARANET TERHADAP SIFAT TOLERANSI TANAMAN TALAS(Colocasia seeculenta (L.) Schoot). Ilmu Pertanian, 10(2), 17-25.

Hani, A. S. dan A. (2014). Produktivitas Talas (Colocasia esculenta L. Shott) di Bawah Tiga Jenis Tegakan dengan Sistem Agroforestri di Lahan Hutan Rakyat. Jurnal Ilmu Kehutanan, 8(2), 100-107.

Heni Purwaningsih and Umi Pudji Astuti. (2018). Superiority Of Japanese Taro (Satoimo) (Colocasia Esculenta Var Antiquorum) As Germplasm Indonesia _ 96356. Agrotechnology. https://doi.org/10.4172/21689881-C2-033

Jensen Uyeda, Ted Radovich, Jari Sugano, A. F. and R. P., \& Water. (2011). Evaluation of irrigation regimes on yield and quality of three cultivars of taro (Colocasia esculenta). Hânai 'Ai / The Food Provider, (May), 1-3.

Jianchu, X., Yongping, Y., Yingdong, P., Ayad, W. G., \& Eyzaguirre, P. B. (2001). Genetic diversity in taro (Colocasia esculenta schott, araceae) in China: An ethnobotanical and genetic approach. Economic Botany, 55(1), 1431. https://doi.org/10.1007/BF02864543

Mishra, A. (2007). Land Suitability Classification for Different Crops. Technology, (1970).

Muhammad Nagano, Sunaryo, dan N. E. S. (2016). STUDI TENTANG APLIKASI KOMPOS UB PADA PERTUMBUHAN DAN HASIL TANAMAN TALAS ( Colocasia esculenta ( L .) Schott var . Antiquorum ) YANG DITANAM DI LAHAN KERING PADA MUSIM KEMARAU STUDY OF UB COMPOST APPLICATION ON GROWTH AND YIELD OF TARO ( Colocasia escule. Jurnal Produksi Tanaman, 4(7), 570-577.

Pribadi, Y. (2016). Analisis Dampak dan Efektivitas Pendampingan Terhadap Adopsi Teknologi PTT dan Produktivitas Padi Sawah di Kecamatan Gambut , Kabupaten Banjar, Kalimantan Selatan. Prosiding Seminar Nasional Inovasi Teknologi Pertanian, 500508.

Raliya, R., Tarafdar, J. C., Gulecha, K., Choudhary, K., Ram, R., Mal, P., \& Saran, R. P. (2013).
Journal of Applied Biology \& Biotechnology. Journal of Applied Biology and Biotechnology. Retrieved from http://jabonline.in/abstract.php?article_id=79\# bottom

Saidah, S., \& Syafruddin, S. (2014). PENGARUH PUPUK ANORGANIK TERHADAP PERTUMBUHAN DAN HASIL TALAS JEPANG DI KABUPATEN BANGGAI KEPULAUAN. In Prosiding Seminar Hasil Penelitian Tanaman Aneka Kacang dan Umbi 2014 (Vol. 1, pp. 867-873). Retrieved from http://balitkabi.litbang.pertanian.go.id/wpcontent/uploads/2015/05/867-873_Saidah1.pdf

Ubalua, A. O., Ewa, F., \& Okeagu, O. D. (2016). Potentials and challenges of sustainable taro (Colocasia esculenta) production in Nigeria. Journal of Applied Biology \& Biotechnology, 60-79. https://doi.org/10.7324/JABB.2016.40110

\begin{tabular}{|c|c|c|c|c|c|c|c|}
\hline No. & Item & & & Unit & Volume & $\begin{array}{l}\text { Unit Price } \\
(\mathrm{Rp})\end{array}$ & T otal Price $(\mathrm{R} p)$ \\
\hline \multicolumn{8}{|c|}{ Biaya SAPRODI } \\
\hline & \multicolumn{2}{|c|}{ Bibit talas satoimo } & & buah & 30,000 & 350 & $10,500,000$ \\
\hline 2 & \multicolumn{2}{|c|}{ Kompos/ppk kand ang } & & $\mathrm{kg}$ & 20,000 & 600 & $12,000,000$ \\
\hline \multirow[t]{4}{*}{$3 y$} & PupukNPK & & & $\mathrm{kg}$ & 1.000 & 2.500 & 2.500 .000 \\
\hline & Pupuk Urea & & & $\mathrm{kg}$ & 250 & 2,000 & 500,000 \\
\hline & Pupuk S P36 & & & $\mathrm{kg}$ & - & 2.200 & \\
\hline & Pupuk KCl & & & $\mathrm{kg}$ & - & 8,100 & \\
\hline 4 & \multirow{2}{*}{\multicolumn{3}{|c|}{$\begin{array}{l}\text { Pupuk cair organik } \\
\text { Kapur Pertani an/selam/abu }\end{array}$}} & liter & 6 & 125.000 & 750.000 \\
\hline & & & & $\mathrm{kg}$ & 1,000 & 900 & 900,000 \\
\hline & \multirow{2}{*}{\multicolumn{2}{|c|}{$\begin{array}{l}\text { Pestisida organik } \\
\text { Perelat (botol) }\end{array}$}} & & liter & 8 & 75.000 & 600.000 \\
\hline & & & & botl & 4 & 35,000 & 140,000 \\
\hline 8 & \multicolumn{2}{|c|}{ Mulsa plas tik } & & paket & - & 4.000 .000 & \\
\hline \multirow{2}{*}{\multicolumn{3}{|c|}{9 Biaya Lis trik }} & & paket & 1 & $1,000,000$ & $1,000,000$ \\
\hline & & & & & & & 28,8 \\
\hline \multicolumn{3}{|c|}{ BIAYA MANAJEMEN } & & PAKET & - & $6,000,000$ & $6,000,000$ \\
\hline \multicolumn{5}{|c|}{ BIAYA OPE RASTONAL dan SE WA LAHAN } & & 50 & \\
\hline \multicolumn{3}{|c|}{\begin{tabular}{|l|l|}
1 & Sew a 1 ahan per MT \\
\end{tabular}} & & ha & 1 & $1,500,000$ & $1,500,000$ \\
\hline & \multicolumn{2}{|c|}{ Sewa dan perawatan ala } & & paket & & 1.000 .000 & 1.000 .000 \\
\hline 3 & \multicolumn{3}{|c|}{ Pengol tn + bedengan (trahtor/cul ivv) } & ha & 1 & $2,000,000$ & $2,000,000$ \\
\hline 4 & \multicolumn{2}{|c|}{ Pemb. lubang tanaman } & & $\mathrm{OH}$ & 25 & 75.000 & 1.875 .000 \\
\hline 5 & \multicolumn{3}{|c|}{ Aplikasi pupukd das ar (torganik) } & $\mathrm{OH}$ & 25 & 75,000 & $1,875,000$ \\
\hline 6 & \multicolumn{3}{|c|}{ Pendederan (traw at-penen $)$ ) } & $\mathrm{OH}$ & 6 & 75.000 & 450.000 \\
\hline & \multicolumn{3}{|c|}{ Biaya Pemasangan mulsa } & $\mathrm{OH}$ & 4 & 75,000 & 300,000 \\
\hline 8 & \multicolumn{3}{|c|}{ Biava penanaman } & $\mathrm{OH}$ & 35 & 75.000 & $2.625,000$ \\
\hline 9 & \multirow{2}{*}{\multicolumn{3}{|c|}{$\begin{array}{l}\text { Biaya pemeliharaan } \\
\text { Biaya panen (tpembersihan) }\end{array}$}} & $\mathrm{OB}$ & 6 & $1,000,000$ & $6,000,000$ \\
\hline & & & & $\mathrm{OH}$ & 50 & 75.000 & 3.750 .000 \\
\hline \multirow{2}{*}{\multicolumn{3}{|c|}{$\begin{array}{l}\text { B iaya trans portasi (ojek) } \\
\text { Jumlah }\end{array}$}} & & sak & 350 & 1.500 & 525.000 \\
\hline & & & & & & & $21,900,000$ \\
\hline & \multirow{2}{*}{\multicolumn{2}{|c|}{ - Total biaya langsung }} & & & & & \\
\hline & & & & & & & $\mathbf{5 6 , 7 9 0 , 0 0 0}$ \\
\hline \multicolumn{2}{|c|}{ Ietal Cost: } & ….......... & & & & & $\mathbf{5 6 , 7 9 0 , 0 0 0}$ \\
\hline \multicolumn{2}{|c|}{ Preduksi } & & 175 & & & & \\
\hline \multicolumn{2}{|c|}{-Umbi utk frozen } & $80 \%$ & 1.30 & les & 26,000 & 3,000 & $78,000,000$ \\
\hline$-U m$ & bi utk tepung & & 0.45 & ke & 9.000 & 2.000 & 18.000 .000 \\
\hline$-\mathrm{Um}$ & bi bibitbonggo & & & buah & 30,000 & 250 & $7,500,000$ \\
\hline Let: & LRerenue: & & & & & & $103,500,000$ \\
\hline Laba & kotor & & & & & & $46,710,000$ \\
\hline $\mathrm{RC}$ & ratio & & ... & ......... & & & 1.82 \\
\hline
\end{tabular}

Tabel Lampiran 1. Hasil analisis BCR talas satoimo di lokasi pelatihan talas satoimo di Kecamatan Sinjai Timur Tahun 2018 